\title{
Growth Performance of Smooth Marron (Cherax cainii) Fed Different Dietary Protein Sources
}

\author{
Ishaaq Saputra ${ }^{1^{*}}$ and Ravi Fotedar ${ }^{2}$ \\ ${ }^{1}$ Fish Quarantine and Inspection Agency Regional Office Jakarta I, Plant and Animal Quarantine \\ Building, Soekarno-Hatta International Airport, Tangerang, Banten, Indonesia \\ ${ }^{2}$ School of Molecular and Life Sciences, Curtin University, Bentley, Western Australia 6102, \\ Australia
}

*Correspondence :

isaputra.6m2@gmail.com

Received : 2020-07-17

Accepted : 2020-11-12

Keywords :

Growth, Marron, Alternative protein, Fish meal replacement

\begin{abstract}
Fish farming including freshwater crayfish still has a dependency on the availability of fish meal as the main source of protein in feed. The purpose of this study was to evaluate alternative protein sources including poultry by-products, feather meal, lupine flour, soybean meal and meat, and bone meal for smooth marron (Cherax cainii) freshwater crayfish feed. A total of 150 juvenile marrons $(9.09 \pm 0.21 \mathrm{~g})$ were kept for 90 days and distributed into 15 rearing tanks consisting of five treatments with three replications. The results indicated that there was no significant difference in the increase in biomass, survival rate, molting rate (weight), feed efficiency ratio, and feed digestibility $(\mathrm{P}>0.05)$. However, marron juvenile fed with a protein source of poultry byproducts meal had the highest specific growth rate $0.31 \pm$ $0.05 \mathrm{~g} /$ day). In addition, marron fed with fish meal protein resulted in a significant increase in carapace length $(\mathrm{P}<0.05)$. Based on the digestibility test, it was found that the digestibility level of the feed ranged from $76.39 \pm 0.01-79.11$ $\pm 0.01 \%$ and replacement of fish meal had no significant effect on dry matter digestibility ( $P>0.05$ ). Overall, the results of this study indicate that the general growth performance of marron is not affected by the replacement of fish meal in the feed. Alternative protein materials can be used as a protein source to replace fish meal in marron feed so that the use of fish meal can be reduced.
\end{abstract}

\section{INTRODUCTION}

The massive use of fish meal as an aquafeed protein resource increase with the expansion of global aquaculture production in the last decades. Attempts to identify fish meal replacement ingredients have become a major concern in the aquaculture industry, including freshwater crayfish (crawfish). Studies on the use of animal-derived protein including poultry by-products, feather meal, meat and bone meal, black soldier fly meal for crawfish diets have been reported (Foysal et al., 2019; Fuertes et al., 2013; 2014). A recent experiment of inclusion poultry by-product meal in the diet of marron crayfish resulted in comparable growth $(0.49 \pm 0.12 \%$ /day $)$ have been reported (Foysal et al., 2019). Apart from animal protein, plant-derived protein such as soybean meal and lupin 
meal have also been considered as alternative dietary protein resources for freshwater crayfish. In C. quadricarinatus, the performance of a juvenile fed diet containing soybean meal as the protein resources was reported to be resulting an acceptable specific growth rate of $4.12 \pm$ $0.3 \%$ /day (Thompson et al., 2005). Besides, a specific growth rate of $1.12 \pm$ $0.15 \%$ /day in marron was reported after the fish meal substitution using lupin meal in the diet under field experimental (Fotedar, 2004).

Smooth marron (Cherax cainii) is one of the eight species within the Cherax genus which native to the Southwestern region of Western Australia and the Southeastern part of Australia. Begun in 1970, marron aquaculture production grows steadily and reach 63.8 tons of its production in the $2017 / 2018$ period with a total value of \$AUD 2.1 million (Steven et al., 2020). Current marron production is focusing on recreational purposes. However, potential aquaculture of this species also needs to be considered. In the Western Australian aquaculture industry, marron has the highest productive licenses compared to other eight cultured species including barramundi, mussels, yabbies, silver perch, goldfish, ornamental invertebrates, ornamental fish and rainbow trout (Steven et al., 2020). Thus, indicated that marron is an important aquaculture commodity. Future marron aquaculture will be affected by the fact that the major protein sources of aquafeed are from the fish meal which is predicted to be limited in the future. To anticipate the problem of fish meal supply, further action is required including finding alternative protein resources for aquaculture diets including those for marron. Although fish meal replacement studies have been conducted on crustacean species, studies of fish meal replacement on the diet of marron are very limited. The present study was designed to evaluate total fish meal replacement by four dietary protein sources, including poultry by-product meal, meat and bone meal, lupin meal and feather meal to the growth performance of juvenile marron and to assess the digestibility of each of these ingredients.

\section{METHODOLOGY}

\section{Place and Time}

The study was conducted at the Curtin University Aquatic Research Laboratory facility, Perth (Western Australia) from June to September 2016.

\section{Research Material}

The material used in the study were marron juvenile weighing $9.09 \pm 0.21$ grams, chromium oxidase, fish meal, feather meal, lupin meal, poultry byproduct meal, meat and bone meal, soybean meal, wheat, corn/wheat starch, betacaine, cod liver oil, cholesterol and casein. The research equipment used were cylindrical fiberglass tanks, pellet extruder, oven, digital water quality checker, analytical balance and digital caliper.

\section{Research Design}

This study used five treatments with three replications. The diet containing fish meal was used as the marron basal feed (K). In the other four diets, fish meal was replaced by feather meal (D1), lupin meal (D2), poultry by-product meal (D3), and meat and bone meal (D4).

\section{Work Procedures}

\section{Marron Juveniles Preparation}

In this study, the marron juveniles $(9.09 \pm 0.21 \mathrm{~g})$ were sourced from Aquatic Resource Management Pty. Ltd. in Manjimup, Western Australia and transported to Curtin University Aquaculture Research Laboratory. Around 200 marron juveniles were acclimated for two weeks in four cylindrical tanks $(500 \mathrm{~L}$ volume) and fed with a commercial marron diet at $3 \%$ of body weight rate per day. At the end of acclimation, a total of 150 survived and healthy marron juveniles were selected and distributed into 15 cylindrical experimental fiberglass tanks 
(10 animal per tank containing $100 \mathrm{~L}$ freshwater and continuous aeration system. Marron was separated individually using clear $750 \mathrm{~mL}$ containers. During the feeding trial, marron juvenile fed five formulated diet at $3 \%$ of body ratio once per day for 90 days of feeding experiment. All uneaten feed and fecal matter were siphoned from the tanks twice a day.

\section{Diets Preparation}

In this study, five different protein sources were used as protein sources of isoenergetic and isonitrogenous marron diets as previously described by Saputra et al. (2019). The quantity of fish meal replacer was adjusted until the final crude protein content around 30 g. $\mathrm{kg}^{-1}$ dry weight basis for each diet (Table 1).

Table 1. Weight (gram dry weight) and proximate analysis of four experimental diets and a reference diet used to evaluate fish meal replacement in marron diets.

\begin{tabular}{|c|c|c|c|c|c|}
\hline \multirow{2}{*}{ Ingredients } & \multicolumn{5}{|c|}{ Diets } \\
\hline & $\mathrm{K}$ & D1 & $\mathrm{D} 2$ & D3 & D4 \\
\hline Fish meal ${ }^{\mathrm{a}}$ & 301.5 & 0 & 0 & 0 & 0 \\
\hline Feather meal ${ }^{\mathrm{a}}$ & 0 & 220 & 0 & 0 & 0 \\
\hline Lupinmeal $^{\mathrm{a}}$ & 0 & 0 & 364 & 0 & 0 \\
\hline Poultry by-product meal & 0 & 0 & 0 & 295 & 0 \\
\hline Meat and bone meal ${ }^{\mathrm{a}}$ & 0 & 0 & 0 & 0 & 243 \\
\hline Soybean meal ${ }^{\mathrm{b}}$ & 108 & 156.5 & 210 & 108 & 166 \\
\hline Wheat & 481.3 & 483.1 & 286.7 & 508.8 & 431.3 \\
\hline Corn/wheat starch ${ }^{\mathrm{b}}$ & 48 & 55 & 40.1 & 48 & 55 \\
\hline Betacaine $^{\mathrm{b}}$ & 12 & 10.2 & 35 & 12 & 35 \\
\hline Cod liver oil ${ }^{\mathrm{b}}$ & 42 & 48 & 34.5 & 21 & 40 \\
\hline Cholesterol $^{\mathrm{b}}$ & 2.5 & 2.5 & 2.5 & 2.5 & 2.5 \\
\hline Casein $^{\mathrm{b}}$ & 2.5 & 22.5 & 25 & 2.5 & 25 \\
\hline
\end{tabular}

${ }^{\mathrm{a}}$ Glen Forest Specialty Feeds, Western Australia

${ }^{\mathrm{b}}$ Talloman, Freemantle, Western Australia

Before the diet production, the protein sources ingredients, soybean meal, and wheat for each diet were sieved using $100 \mu \mathrm{m}$ mesh screens. The mixture was then added with the rest of the ingredients and mixed thoroughly with the addition of a small amount of distilled water. Additional calcium carbonate $(0.2 \mathrm{~g})$, ascorbic acid (0.5 g), and vitamin premix (1.5 g) was added to each tested diet prior to pellet production. The dough was then processed with a pellet extruder to produce pellets (3 $\mathrm{mm}$ diameter) that were then dried in the oven at $60{ }^{\circ} \mathrm{C}$ for approximately 24 hours. Following diet production completion, the chemical parameter of the diet including ash content, gross energy and crude protein content were analyzed.

Table 1. Proximate Composition of Tested diets (g.kg-1 dry weight basis).

\begin{tabular}{|c|c|c|c|c|c|}
\hline \multirow{2}{*}{ Parameters } & \multicolumn{2}{|c|}{ Diet } & \multirow[b]{2}{*}{ D2 } & \multirow[b]{2}{*}{ D3 } & \multirow[b]{2}{*}{ D4 } \\
\hline & $\mathrm{K}$ & D1 & & & \\
\hline DM\% & 89.07 & 87.85 & 88.46 & 87.86 & 87.26 \\
\hline Ash\% & 8.24 & 3.18 & 6.21 & 4.05 & 10.13 \\
\hline GE MJ/kg & 18.63 & 18.39 & 18.59 & 18.57 & 18.34 \\
\hline СР\% & 30.13 & 30.46 & 30.84 & 30.88 & 30.18 \\
\hline
\end{tabular}

\section{Data Collection Growth}

All marron juveniles were measured and weighed at the commencement of the feeding trial, at day 30 , day 60 , and day 90. Percentage weight gain and specific growth rate (SGR) were determined using the formulae (Tan et al., 2018) as follows: 
Weight Gain $(\%)=\frac{100 \times(\mathrm{Wt}-\mathrm{W} 0)}{\mathrm{W} 0}$

SGR/day $(\%)=\frac{100 \times(\ln W \mathrm{t}-\ln \mathrm{W} 0)}{\mathrm{t}}$

Note:

$\mathrm{W}_{\mathrm{t}}=$ weight at the time intervals sampled

$\mathrm{W}_{0}=$ weight at the commencement of the experiment

$\mathrm{t}=$ experiment period (days)

The feed efficiency ratio (FER) was calculated following equation:

$\mathrm{FER}=\frac{\text { weight gain }}{\text { feed mass consumed }}$

The molting rate was calculated as follows:

MR (\%) $=100 \times \frac{\text { Emoulting marron }}{\text { Emarron }}$

$\operatorname{MI}(\%)=100 x \frac{\text { weight after moult-initial weight }}{\text { weight before moult }}$

BI $(\%)=100 \times \frac{\text { Final biomass-Initial biomass }}{\text { Initial biomass }}$

Note:

$\mathrm{MI}=$ molt increment

$\mathrm{BI}=$ biomass increment

\section{Pellet Stability and Digestibility}

Tested feeds from the original studies were used in subsequent digestibility study by incorporating $1 \%$ of chromium oxide $\left(\mathrm{Cr}_{2} \mathrm{O}_{3}\right)$. The diet was reproduced with the addition of $1 \% \mathrm{Cr}_{2} \mathrm{O}_{3}$. The digestibility study was carried out for 10 days using seven marron juveniles in a similar experimental system to that of the first diet study. The fecal matter was monitored and collected twice per day after feeding and stored in a beaker glass until ready for analysis. The digestibility was measured in terms of the percentage of total dry matter digested.

To assess the quality of the tested diet, pellet water stability, and digestibility study was performed. Pellet stability was determined based on the leaching rate of the diets in the water at 10 minutes and 60 minutes. Six replicates of two grams of each diet were prepared by transfer it into $150 \mathrm{~mL}$ glass beakers containing $50 \mathrm{ml}$ of distilled water. After the water immersion time was completed, water in the beaker glass was then siphoned off until the minimum level was reached. Feed samples were then dried at $60^{\circ} \mathrm{C}$ for 48 hours and then the percent dry matter loss was calculated using the following equation:
DM loss $(\%)=\frac{\text { dry weight }}{\text { wet weight }} \times 100$

To assess the $\mathrm{Cr}_{2} \mathrm{O}_{3}$ concentration in each sample, approximately $0.1 \mathrm{~g}$ of each sample was transferred to an assigned digestion tube and $5 \mathrm{~mL}$ of $70 \% \mathrm{HNO}_{3}$ was added. All tubes were then placed in the digester (Foss Tecator Digestor 8, Sweden) for 20 minutes at $300^{\circ} \mathrm{C}$. Three $\mathrm{mL}$ of $70 \%$ perchloric acid was added to each sample after the digestion process. The reheating process changed the sample color from green to yellow or orange. The samples were then diluted into $50 \mathrm{~mL}$ distilled water and transferred into 100 $\mathrm{mL}$ flasks. Distilled water was added to each flask to obtain $100 \mathrm{~mL}$ total volume. The amount of $\mathrm{Cr}_{2} \mathrm{O}_{3}$ both in the diet and feces were measured photometrically (S20 spectrophotometer, Boeco, Germany) by comparing its absorbance with the standard curve at $350 \mathrm{~nm}$ of wavelength. A standard curve was made by diluting a series of $0.2,0.4,0.8,1,1.4,1.8$, and $2 \mathrm{mg}$ of chromium oxide into $100 \mathrm{~mL}$. The concentration of chromium oxide $(\mathrm{mg} / 100 \mathrm{~mL})$ both in feed and feces samples were determined by plotting the stock solution concentration against the average absorbance reading as described by Jones and De Silva (1998) using the equation:

$$
\mathrm{Cr}_{2} \mathrm{O}_{3} \text { Concentration }(\%)=\frac{\mathrm{C}}{\mathrm{W}}
$$

Note:

$\mathrm{C}=$ concentration $(\mathrm{mg} / 100 \mathrm{~mL})$

$\mathrm{W}=$ weight of the original sample (mg)

Apparent digestibility dry matter (ADMD) of each feed types was measured using the following equation:

$\mathrm{TD}(\%)=\frac{100-(1(\% \text { marker in feed })}{\% \text { marker in faeces }}$

Note:

$\mathrm{TD}=$ total digestibility

\section{Data Analysis}

Statistical analyses were performed to determine the effect of feeding treatment on the physiological responses and diet performance of marron. All data were analyzed using parametric analysis in SPSS version 25.0 software. Results are presented as mean and standard error 
values. The significant difference from each treatment was evaluated using randomized block design and analysis of variance ANOVA. The least significant difference posts hoc test tests were performed to determine significant differences amongst treatment groups and results were determined as significant at $\mathrm{P}$ $<0.05$.

\section{RESULTS AND DISCUSSION}

Attempts on the evaluation of fish meal replacement in freshwater crayfish diets have been reported with various results (Fotedar, 2004; Foysal et al., 2019; Fuertes et al., 2012, 2013; Tan et al., 2018). As shown in Table 3, after 90 days of the feeding trial, the mean of the specific growth rate of marron juvenile fed with different dietary protein sources was not significantly different $(P>0.05)$. The mean of the specific growth rate is ranging from 0.21 to $0.31 \%$ per day (Figure 1). Similar results were also observed in survival rate, feed conversion rate and feed efficiency rate among any marron juveniles fed with the test diets (Table 3 ).

Table 3. Specific growth rate, survival rate, FCR, and FER (mean \pm SE values). Data with different superscript $\left({ }^{a, b}\right)$ in the same row indicate significantly different at $\mathrm{P}<0.05$ over periods.

\begin{tabular}{lccccc}
\hline \multirow{2}{*}{ Aspects } & \multicolumn{5}{c}{ Diets Treatment } \\
\cline { 2 - 6 } & $\mathrm{K}$ & $\mathrm{D} 1$ & $\mathrm{D} 2$ & $\mathrm{D} 3$ & \multicolumn{1}{c}{$\mathrm{D} 4$} \\
\hline SGR (\% day $^{-1}$ ) & $0.27 \pm 0.02^{\mathrm{a}}$ & $0.29 \pm 0.01^{\mathrm{a}}$ & $0.21 \pm 0.02^{\mathrm{a}}$ & $0.31 \pm 0.05^{\mathrm{a}}$ & $0.30 \pm 0.05^{\mathrm{a}}$ \\
SR $(\%) *^{\text {FCR * }}$ & $90.00 \pm 0.58$ & $83.33 \pm 1.20$ & $100.00 \pm 00$ & $90.00 \pm 0.58$ & $96.67 \pm 0.33$ \\
FER & $2.94 \pm 0.26^{\mathrm{a}}$ & $2.47 \pm 0.31^{\mathrm{a}}$ & $3.79 \pm 0.46^{\mathrm{a}}$ & $2.78 \pm 0.62^{\mathrm{a}}$ & $2.26 \pm 0.45^{\mathrm{a}}$ \\
& $11.40 \pm 0.98^{\mathrm{a}}$ & $13.72 \pm 1.60^{\mathrm{a}}$ & $9.01 \pm 1.22^{\mathrm{a}}$ & $13.37 \pm 3.44^{\mathrm{a}}$ & $15.65 \pm 2.62^{\mathrm{a}}$ \\
\hline
\end{tabular}

There were also no significant differences $(\mathrm{P}>0.05)$ in the molting rate and weight molt increment of the marron juveniles fed without fish meal in the diet.
However, marron fed with diet containing $\mathrm{K}$ showed a significantly longer $(\mathrm{P}<0.05)$ molt increment compared with tested diets (Table 4).

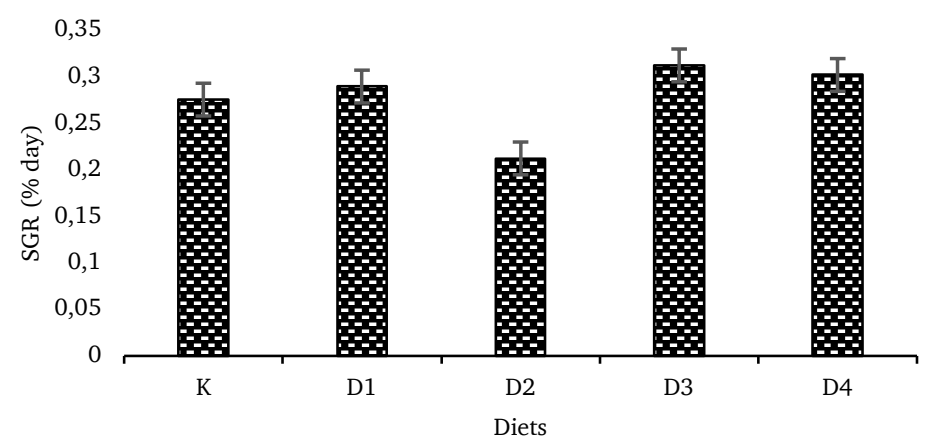

Figure 1. The specific growth rate of marron fed with different dietary protein sources. Bar with different superscript $\left({ }^{\mathrm{a}, \mathrm{b}}\right)$ indicates significantly different at $\mathrm{P}<0.05$ over time periods.

The specific growth rate in the present study was comparable to previous experiments on marron (Ambas et al., 2013; Foysal et al., 2019). The probiotic supplementation on marron diets resulted in an SGR value of 0.27 to $0.51 \%$ /day (Ambas et al. 2013), while Foysal et al. (2019) reported the SGR value of marron was 0.49 to $0.53 \%$ /day after 60 days of feeding trial. In contrast, growth rates obtained in this study were lower than the results from previous studies using earthen pond culture systems (Fotedar, 2004). The lower growth rate obtained in the present study can be attributed to the shorten feeding trial period. The feeding 
trial conducted by Fotedar (2004) was lasted for 10 months and under a semiintensive culture system rather than under laboratory conditions. Another factor that may affect the low SGR value may be attributed to characteristics of the species. The consistent higher SGR value of other crayfish species has been reported. In $C$. quadricarinatus the SGR was reported between $3.43-3.95 \%$ /day (Thompson et al., 2010) while the SGR in P. clarkii was reported to be $1.02-2.43 \%$ /day (Hua et al., 2015; Tan et al., 2018).
The inclusion of any types of protein resources in the diets did not affect the apparent digestibility of dry matter of the diets (Table 4). However, at both periods of water immersion, the mean of total dry matter loss of diet containing fish meal was significantly higher $(\mathrm{P}<0.05)$ than the other diets (Figure 3 ). In contrast, diet D3 was significantly low $(\mathrm{P}<0.05)$ at 10 minutes of water exposure. Each type of feed was not significantly affecting the water quality during the experiment period.

Table 4. Molting rate, molt weight increment, molt length increment, apparent digestibility of dry matter for marron fed four test diets and a control diet (K) after 90 days of culture (mean \pm SE values). Data with different superscripts $(1,2)$ in the same row indicate significantly different at $\mathrm{P}<0.05$ overtime periods.

\begin{tabular}{lccccc}
\hline \multirow{2}{*}{ Aspects } & \multicolumn{5}{c}{ Diets Treatment } \\
\cline { 2 - 6 } & $\mathrm{K}$ & $\mathrm{D} 1$ & $\mathrm{D} 2$ & $\mathrm{D} 3$ & $\mathrm{D} 4$ \\
\hline MR & $50.00 \pm 5.77^{\mathrm{a}}$ & $43.33 \pm 6.67^{\mathrm{a}}$ & $66.67 \pm 13.33^{\mathrm{a}}$ & $53.33 \pm 3.33^{\mathrm{a}}$ & $73.33 \pm 8.82^{\mathrm{a}}$ \\
MI weight & $30.90 \pm 5.98^{\mathrm{a}}$ & $19.54 \pm 4.51^{\mathrm{a}}$ & $19.71 \pm 1.78^{\mathrm{a}}$ & $25.30 \pm 3.75^{\mathrm{a}}$ & $26.74 \pm 3.2^{\mathrm{a}}$ \\
MI length & $11.39 \pm 1.21^{\mathrm{a}}$ & $6.24 \pm 0.66^{\mathrm{b}}$ & $6.77 \pm 0.47^{\mathrm{b}}$ & $9.77 \pm 1.48^{\mathrm{b}}$ & $7.32 \pm 1.38^{\mathrm{b}}$ \\
ADMD & $76.96 \pm 0.02^{\mathrm{a}}$ & $77.89 \pm 0.02^{\mathrm{a}}$ & $77.33 \pm 0.02^{\mathrm{a}}$ & $76.39 \pm 0.01^{\mathrm{a}}$ & $79.11 \pm 0.01^{\mathrm{a}}$ \\
\hline
\end{tabular}

Previous fish meal replacement experiment using similar diets ingredients was reported by Saputra et al. (2019) with emphasis on the immunological aspects. Results indicated that immunological conditions of marron were affected by the total inclusion of fish meals. In contrast, the substitution of fish meal with several other dietary protein sources did not affect the survival rate of marron juvenile and feed conversion ratio. A similar high survival rate from equivalent feeding trials was also reported in other crawfish species (Fuertes et al., 2012; 2013). It is difficult to link the direct impact of the protein sources in the diets with the survival rate, however, the isolation system as used in that study had a positive effect on the survival rate. That method can reduce the cannibalism behavior of marron especially during the molting period as reported by Fuertes et al. (2013). Feed conversion ratios obtained in the study were slightly lower than data reported (Hua et al., 2015) and higher than P. clarkii (Tan et al., 2018). Although the results were not significantly different between the treatments, diets containing meat and bone meal exhibited the same FCR as all the other treatments. This similar FCR reflects the same diet utilization. Similarly, the diets containing meat and bone meal had the same ADMD value as all the other diets. Association of the ADMD value and FCR does not warrant further investigation based on these results.

Biomass increment is strongly associated with the growth of marron and has been used to determine the growth of crayfish in feeding trial experiments (Ambas et al., 2013). In the present study, different protein sources had no effect on the BI of marron fed different test diets. The biomass increment varied from $21.54 \%$ to $33.71 \%$ at the end of the experiment. Although other attempts to increase BI have been conducted by the administration of customized probiotics into the marron, the result was not positive (Ambas et al., 2013). 


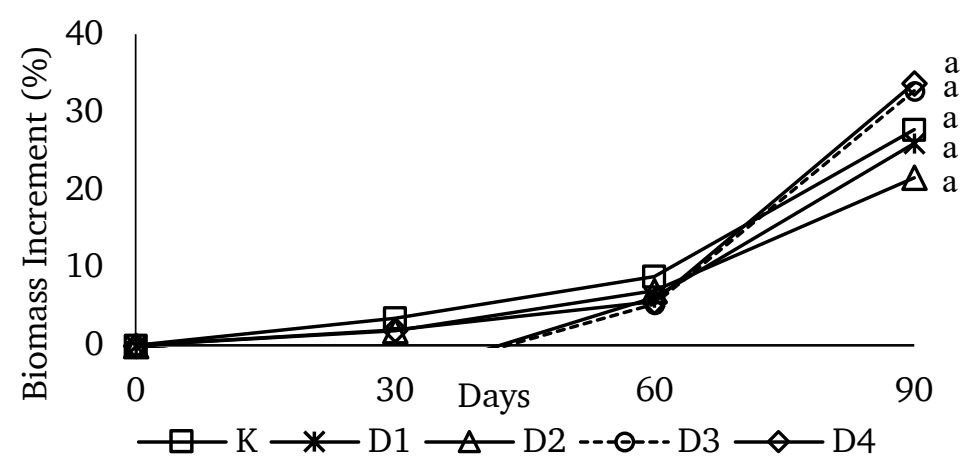

Figure 2. Biomass increment of marron juveniles fed with test diets with different protein sources. Data with different superscript $\left({ }^{\mathrm{a}, \mathrm{b}}\right)$ on the top symbol indicate significantly different at $\mathrm{P}<0.05$ overtime periods.

The molt increment can be determined using the increment of the bodyweight (Jones et al., 1996) and carapace length (Salama and Hartnoll, 1992). The weight increment after molting of marron in the present study ranged from 19.54 to $30.90 \%$ which is in line with the results from Jussila and Evans (1996). The findings of the incorporation of fish meal protein effectively increase the carapace length increment of marron juveniles in the present study is a significant result. Evaluation of the effect of protein sources in diets on the molting rate of freshwater crayfish is very limited. However, the fish meal inclusion combined with the protein levels in the diets of yabby has been reported to be strongly correlated with its molting rate (Jones et al., 1996). In the present study, results varying among the treatments and the average molting rate is $57.33 \%$. The average molting rate of the current study is comparable to a previous study molting rate of marron which was only $44.1 \pm 13.7 \%$ (Rouse and Kartamulia, 1992).

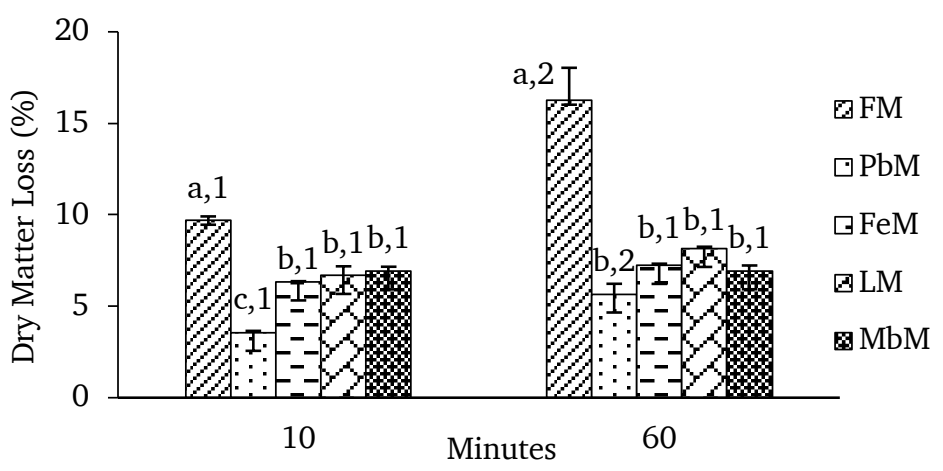

Figure 1. Total dry matter loss (\%) test diets after 10 minutes and 60 minutes of water exposure. Data with different superscripts $\left({ }^{\mathrm{a}, \mathrm{b}}\right)$ on the top bar indicate significantly different at $\mathrm{P}<0.05$ within periods. Data with different superscript $\left({ }^{1,2}\right)$ on the top bar indicate significantly difference at $\mathrm{P}<0.05$ between periods.

Apparent dry matter digestibility of diets in the present study was not significantly influenced by the dietary protein source, which ranged from $76.29 \%$ to $79.11 \%$. Similar to our data results, two previous digestibility studies performed on crayfish (Jones and De Silva, 1998) resulted in high ADMD. Furthermore, according to the present dietary experiments, high diet stability in water was achieved in all diets tested and the leaching rate off all diets at 60 minutes 
of water immersion was very low. That results were reflected by the optimum condition of water quality during the experiment period (Table 5).

Table 5. Water quality of treatment tanks. Data with different superscript $\left({ }^{\mathrm{a}, \mathrm{b}}\right)$ in the same row indicate significantly different at $\mathrm{P}<0.05$ overtime periods.

\begin{tabular}{lccccc}
\hline \multirow{2}{*}{ Water Quality } & \multicolumn{5}{c}{ Treatments } \\
\cline { 2 - 6 } & $\mathrm{K}$ & $\mathrm{D} 1$ & $\mathrm{D} 2$ & $\mathrm{D} 3$ & $\mathrm{D} 4$ \\
\hline Temperature & $20.1 \pm 0.68^{\mathrm{a}}$ & $19.7 \pm 0.28^{\mathrm{a}}$ & $19.4 \pm 0.58^{\mathrm{a}}$ & $19.6 \pm 0.27^{\mathrm{a}}$ & $19.1 \pm 0.34^{\mathrm{a}}$ \\
DO (mg/L) & $8.51 \pm 0.18^{\mathrm{a}}$ & $8.54 \pm 0.11^{\mathrm{a}}$ & $8.65 \pm 0.07^{\mathrm{a}}$ & $8.77 \pm 0.04^{\mathrm{a}}$ & $8.65 \pm 0.07^{\mathrm{a}}$ \\
pH & $8.07 \pm 0.01^{\mathrm{a}}$ & $8.09 \pm 0.01^{\mathrm{a}}$ & $8.04 \pm 0.02^{\mathrm{a}}$ & $7.95 \pm 0.02^{\mathrm{a}}$ & $8.08 \pm 0.01^{\mathrm{a}}$ \\
Ammonia & $<0.05$ & $<0.05$ & $<0.05$ & $<0.01$ & $<0.05$ \\
\hline
\end{tabular}

Feed quality is one of several potential constraints in aquaculture activity. Poor feed quality will increase the ammonia level in the water and can be exacerbated by improper feed management. Improving FCR and stability of pelleted diet are possible mitigation strategies to reduce the adverse impact of poor-quality feed. Using optimum nutrient requirements and higher ingredients digestibility are also can be considered to maintain the water quality. The current study demonstrated that fish meal ingredients can be replaced completely by using other protein sources without negative effects on the general growth and other biological condition on marron juveniles. In addition, the total fish meal inclusion as protein resources in the diets did not affect the quality of the diets. Results of this study contribute to the body of knowledge of marron nutrition, as there was a limited record of the study that had been undertaken on the substitution of alternative protein resources in marron juvenile diets.

\section{CONCLUSION}

In conclusion, the fish meal replacement in marron juvenile diets did not impair the growth, feed efficiency ratio, molt increment weight, and molting rate. However, a noticeable effect on total fish meal inclusion was observed in molt increment length of marron. In terms of feed quality, the digestibility and diet stability study indicated that the diets are acceptable for marron culture. Therefore, the use of alternative protein sources might be considered in commercial marron farming in the future.

\section{ACKNOWLEDGMENT}

This work was financially funded by Australia Awards Scholarship (AAS) program Grant ID 13/03652 to the first author. We would like to thanks to Talloman-Craig Mostyn Group and Aquatic Resource Management Pty. Ltd for the diet ingredients. The authors also thank all Curtin Aquatic Research Laboratory (CARL) staff for the support of the trial facility.

\section{REFERENCES}

Ambas, I., Suriawan, A. and Fotedar, R., 2013. Immunological responses of customised probiotics-fed marron, Cherax tenuimanus, (Smith 1912) when challenged with Vibrio mimicus. Fish \& Shellfish Immunology, 35(2), pp.262-270. http://dx.doi.org/10.1016/j.fsi.201 3.04 .026

Fotedar, R., 2004. Effect of dietary protein and lipid source on the growth, survival, condition indices, and body composition of marron, Cherax tenuimanus (Smith). Aquaculture, 230(1-4), pp.439-455. http://dx.do i.org/10.1016/S0044-8486(03)004 18-6

Foysal, M.J., Fotedar, R., Tay, C.Y. and Gupta, S.K., 2019. Dietary supplementation of black soldier fly (Hermetica illucens) meal modulates gut microbiota, innate immune response and health status of marron (Cherax cainii, Austin 2002) 
fed poultry-by-product and fis meal based diets. PeerJ, 7, e6891. https:// doi.org/10.7717/peerj.6891

Fuertes, J.B., Celada, J.D., Carral, J.M., Sáez-Royuela, M. and GonzálezRodríguez, Á., 2012. Effects of dietary protein and different levels of replacement of fish meal by soybean meal in practical diets for juvenile crayfish (Pacifastacus leniusculus, Astacidae) from the onset of exogenous feeding. Aquaculture, 364-365, pp.338-344. http://dx.doi.org/10.1016/j.aquacu lture.2012.08.050

Fuertes, J.B., Celada, J.D., Carral, J.M., Sáez-Royuela, M. and GonzálezRodríguez, Á., 2013. Replacement of fish meal with poultry by-product meal in practical diets for juvenile crayfish (Pacifastacus leniusculus Dana, Astacidae) from the onset of exogenous feeding. Aquaculture, 404-405, pp.22-27. http://dx.doi.or $\mathrm{g} / 10.1016 /$ j.aquaculture.2013.04.0 19

Fuertes, J.B., Celada, J.D., Carral, J.M., Sáez-Royuela, M. and GonzálezRodríguez, Á., 2014. Effects of fish meal replacement by feather meal in practical diets for juvenile crayfish (Pacifastacus leniusculus Dana, Astacidae). Aquaculture Nutrition, 20(1), pp.36-43. https://doi.org/10 $.1111 /$ anu. 12044

Hua, X.M., Shui, C., He, Y.D., Xing, S.H., Yu, N., Zhu, Z.Y. and Zhao, C.Y., 2015. Effects of different feed stimulants on freshwater crayfish (Procambarus clarkii), fed diets with or without partial replacement of fish meal by biofeed. Aquaculture Nutrition, 21(1), pp.113-120. https: //doi.org/10.1111/anu.12148

Jones, P.L. and De Silva, S.S., 1998. Comparison of internal and external markers in digestibility studies involving the Australian freshwater crayfish, Cherax destructor Clark (Decapoda, Parastacidae). Aquaculture Research, 29(7), pp.487-493. https://doi.org/10.104 6/j.1365-2109.1998.00231.x

Jones, P.L., De Silva, S.S. and Mitchell, B.D., 1996. Effects of replacement of animal protein by soybean meal on growth and carcass composition in juvenile Australian freshwater crayfish. Aquaculture International, 4(4), pp.339-359. https://doi.org/1 $0.1007 /$ bf00120950

Jussila, J. and Evans, L.H., 1996. On the factors affecting marron, Cherax tenuimanus, growth in intensive culture. Freshwater crayfish, 11, pp.428-440. https://www.astacolog y.org/FCmobileAbstracts.asp?uid = Guest\&mid $=532 \& \mathrm{v}=11 \& \mathrm{i}=1$

Rouse, D.B. and Kartamulia, I., 1992. Influence of salinity and temperature on molting and survival of the Australian freshwater crayfish (Cherax tenuimanus). Aquaculture, 105(1), pp.47-52. http://dx.doi.org /10.1016/0044-8486(92)90160-M

Salama, A.J. and Hartnoll, R.G., 1992. Effects of food and feeding regime on the growth and survival of the prawn Palaemon Elegans Rathke, 1837 (Decapoda, Caridea). Crustaceana, 63(1), pp.11-22. http://dx.doi.org/10.1163/156854 092X00235

Saputra, I., Fotedar, R., Gupta, S.K., Siddik, M.A.B. and Foysal, M.J., 2019. Effects of different dietary protein sources on the immunological and physiological responses of marron, Cherax cainii (Austin and Ryan, 2002) and its susceptibility to high temperature exposure. Fish \& Shellfish Immunology, 88, pp.567-577. https://doi.org/10.1016/j.fsi.2019. 03.012

Steven, A., Mobsby, D. and Curtotti, R., 2020. Australian fisheries and aquaculture statistics 2018, Fisheries Research and Development Corporation project 2019-093. Canberra: ABARES.

Tan, Q., Song, D., Chen, X., Xie, S. and Shu, X., 2018. Replacing fish meal 
with vegetable protein sources in feed for juvenile red swamp crayfish, Procambarus clarkii: Effects of amino acids supplementation on growth and feed utilization. Aquaculture Nutrition, 24(2), pp.858-864. https://doi.org/10.111 1/anu.12621

Thompson, K.R., Bailey, T.J., Metts, L.S., Brady, Y.J. and Webster, C.D., 2010. Growth response and fatty acid composition of juvenile red claw crayfish (Cherax quadricarinatus) fed different sources of dietary lipid. Aquaculture Nutrition, 16(6), pp.604-615. https://doi.org/10.111 1/j.1365-2095.2009.00697.x

Thompson, K. R., Muzinic, L.A., Engler, L.S. and Webster, C.D., 2005. Evaluation of practical diets containing different protein levels, with or without fish meal, for juvenile Australian red claw crayfish (Cherax quadricarinatus). Aquaculture, 244(1-4), pp.241-249. https://dx.doi.org/10.1016/j.aquac ulture.2004.11.018 